\title{
Literatura em alto e bom som: experiência e materialidade em leituras literárias coletivas
}

\author{
Mei Hua Soares*
}

\begin{abstract}
[...] as situações de leitura são historicamente variáveis. A leitura é sempre um ato de foro íntimo, secreto, que reenvia à individualidade? Não, porque esta situação de leitura não foi sempre dominante. Creio, por exemplo, que nos meios urbanos, entre os séculos XVII e XVIII, existe todo um outro conjunto de relações com os textos que passa pelas leituras coletivas, leituras que manipulam o texto, decifrado de uns para outros, por vezes elaborado em comum, o que põe em jogo alguma coisa que ultrapassa a capacidade individual de leitura.
\end{abstract}

Roger Chartier, em Práticas da leitura.

E uma luzinha quase imperceptível surgia longe, apagava-se, ressurgia, vacilante, nas trevas do meu espírito.

Graciliano Ramos, em Infância.

Em Uma história da leitura, Alberto Manguel recupera um curioso episódio social e político da história da leitura ocidental. Na segunda metade do século XIX, o jornalista Saturnino Martínez, fundador do jornal La Aurora ${ }^{1}$ (1865), buscando ampliar a difusão de suas publicações e considerando o analfabetismo preponderante na população, propõe a inserção da peculiar figura do lector - um leitor oficial - em fábricas de charuto cubanas. A fábrica pioneira nessas práticas foi a El Fígaro, seguida por outras. Durante as jornadas de trabalho, operários e operárias passaram a realizar seus trabalhos, essencialmente manuais, ao som das leituras de notícias, artigos, poemas e romances, uma vez que o jornal trazia em seus conteúdos textos informativos e literários. Mas, dado o caráter subversivo atribuído à prática, as leituras e o lector (geralmente ele mesmo um dos operários) foram impedidos de permanecer atuantes. Uma vez instaurada a prática de leitura em meio

\footnotetext{
Doutora e Mestra em Linguagem e Educação pela Faculdade de Educação da Universidade de São Paulo (FE-USP), SP, Brasil. Docente do curso de Comunicação Social da Faculdade Cásper Líbero, São Paulo, SP, Brasil. E-mail: meihuasoares@gmail.com.

1 "Ao longo dos anos, La Aurora publicou trabalhos dos principais escritores cubanos da época, bem como traduções de autores europeus como Schiller e Chateaubriand, críticas de livros e peças de teatro e denúncias sobre tirania dos donos das fábricas e o sofrimento dos trabalhadores. Em 27 de junho de 1866, perguntava aos seus leitores: 'Sabem que perto de La Zanja, segundo dizem, há um dono de fábrica que põe grilhões nas crianças usadas por ele como aprendizes?’” (MANGUEL, 1997, p. 133).
} 
ao grupo de trabalhadores - da qual decorriam reflexões e diálogos em pares ou conjuntamente sobre aspectos imbricados nos textos lidos -, percebeu-se o risco envolvido na formação de leitura dos envolvidos.

Em maio de 1866, após apenas quatro meses do início das práticas públicas de leitura, o então governador político de Cuba baixou um decreto ${ }^{2}$ proibindo-as. Leituras clandestinas aconteciam apesar do decreto, mas de acordo com os registros existentes, acabaram desaparecendo em meados de 1870 . Leituras dessa ordem aconteceram também em solo norte-americano, com trabalhadores que para lá emigraram levando consigo a instituição do lector e das leituras públicas. Mario Sánchez, um pintor filho de lector cubano, em relato sobre a atividade paterna, descreve a rotina de leitura dividida em leitura do noticiário internacional, no turno da manhã, e de romances na parte da tarde. A formação de leitura dos operários, que se efetuava essencialmente pela escuta e memorização, conforme Manguel (1997, p. 136), ressignificava seus ofícios:

Os operários que haviam trabalhado muitos anos nas fábricas eram capazes de citar de memória longos trechos de poesia, e mesmo de prosa. [...] Ouvir alguém lendo para eles, descobriram os charuteiros, permitia-lhes revestir a atividade de enrolar as folhas escuras do tabaco - atividade mecânica e entorpecedora da mente - com aventuras a seguir, ideias a levar em consideração, reflexões das quais se apropriar.

O exemplo histórico de uma prática de leitura pública específica pode trazer à tona questões relacionadas a leituras realizadas coletivamente na contemporaneidade. Quando nos reportamos à leitura de literatura, geralmente nos vêm à mente as leituras silenciosas, individuais e solitárias, o que parece confirmar a predominância de uma determinada prática de leitura literária em detrimento de outras. Certamente todas são válidas e há aspectos semelhantes nas leituras íntimas ou públicas de textos. Por exemplo: o acionamento das dimensões subjetivas e o preenchimento de lacunas por parte do leitor.

Mas o que gostaríamos de esmiuçar, principalmente porque nos interessa registrar práticas coletivas de leitura literária que existem (e resistem) na atualidade, são os elementos envolvidos quando ouvimos (acompanhados do texto impresso ou não) literatura em diferentes agrupamentos humanos. Aqui nos reportaremos a leituras coletivas realizadas em voz alta em: 1) um grupo teatral paulistano subsidiado pelo programa de Fomento para a Cidade de São Paulo; 2) uma turma de $3^{\circ}$ ano do ensino médio de uma escola pública estadual paulistana e 3) uma turma de graduação $\left(1^{\circ}\right.$ ano) do curso de Comunicação Social em uma fundação.

\footnotetext{
2 "O decreto consistia nos seguintes incisos: 1. É proibido distrair os trabalhadores das fábricas de tabaco, oficinas e fábricas de todo tipo com a leitura de livros e jornais, ou com discussões estranhas ao trabalho em que estão empenhados. 2. A polícia deve exercer vigilância constante para fazer cumprir este decreto e colocar à disposição de minha autoridade os donos de fábricas, representantes ou gerentes que desobedeçam a esta ordem, de modo que possam ser julgados pela lei, segundo a gravidade do caso" (MANGUEL, 1997, p. 134).
} 
O referencial teórico, as aporias e apontamentos que aqui se delineiam são fruto de vivências experimentadas durante o percurso docente da pesquisadora, do doutorado, e de projetos realizados junto ao Centro Interdisciplinar de Pesquisas da Faculdade Cásper Líbero (CIP- FCL) e ao Grupo de Pesquisa Linguagens na Educação da Universidade de São Paulo (FEUSP).

\section{Espetacularização e corporeidade nas leituras}

A reflexão (epígrafe) de Roger Chartier sugere variações nos modos de ler em virtude de transformações históricas nas relações sociais e culturais. Ou seja, reflexamente as práticas de leitura se alteram na medida em que outras práticas sociais igualmente sofrem modificações. As leituras realizadas em contextos de interação efetuados em meios digitais, em redes sociais, são marcadas por alternâncias, recortes, ritmo e velocidade que diferem das leituras realizadas em meios e veículos impressos, por exemplo. Consequentemente, a atenção e a concentração também sofrem mutações. Textos verbais são frequentemente acompanhados de imagens informativas e publicitárias disparadas de modo intervalado, mas contínuo, caracterizando as leituras por um excesso de estímulo visual e fragmentação. A esse respeito, o teórico de arte Jonathan Crary, em estudo sobre a percepção na sociedade do espetáculo, salienta as conformações e riscos envolvidos na predominância da visualidade como dispositivo responsável por capturar a atenção do leitor/espectador, afastando-o de uma percepção corporal mais abrangente e resistente aos efeitos da espetacularização, e sugere que "formas de contra-atenção" envolvem outras temporalidades e modos de cognição:

[...] a "visualidade" pode facilmente desviar-se para um modelo de percepção e subjetividade que se afasta da ideia de "corporeidade", mais rica e historicamente determinada, na qual um sujeito "corporificado" é ao mesmo tempo o local de operações de poder e o potencial de resistência a elas. [...] a cultura do espetáculo não está fundada na necessidade de fazer um sujeito ver, mas em estratégias pelas quais os indivíduos se isolam, se separam e habitam o tempo destituídos de poder. Do mesmo modo, as formas de contra-atenção não são exclusiva ou essencialmente visuais, mas constituídas com outras temporalidades e estados cognitivos, tais como os que ocorrem no transe e no devaneio (CRARY, 2013, p. 27).

Nesse sentido, aventamos a leitura literária como contraponto a formas de recepção acionadas por dispositivos que visam à submissão a efeitos espetacularizados e à captura da atenção como finalidade principal. E questionamo-nos se, especificamente as leituras de literatura em voz alta, coletivas e públicas - como as realizadas nas fábricas cubanas -, ao mobilizarem materialidades outras que não apenas a visual, contribuiriam para fomentar outras recepções que escapem do controle e cooptação vigentes em práticas que evocam apenas sensações visuais. 


\section{Anton Tchekhov à exaustão: luzes na leitura teatral}

Em pesquisa de doutorado sobre práticas coletivas de leitura, ${ }^{3}$ pude acompanhar, ao longo de um ano, leituras e ensaios de dois grupos teatrais paulistanos durante seus processos de criação e encenação. A proposta era observar elementos presentes nessas práticas (desenvolvidas junto a um público essencialmente jovem) e em que medida eles poderiam ser adaptados a práticas escolares de leitura. Ambos os grupos mantinham (e mantêm) trabalhos há mais de quinze anos e é possível identificar em seus programas potentes projetos formativos, fator que motivou a escolha de pesquisa.

Um dos grupos, a Cia. Antropofágica (e seu núcleo de formação, PY), mantinha em sua rotina de trabalho uma noite em que eram estudados, experimentados e ensaiados textos durante doze horas seguidas, com pausas apenas para o jantar e para idas ao banheiro. Durante as sextas-feiras, portanto, o ensaio acontecia das $19 \mathrm{~h}$ às $7 \mathrm{~h}$ da manhã de sábado. Em dois desses longos encontros, uma leitura coletiva propiciou uma recepção peculiar, uma vez que, pelo conjunto de fatores que se entrelaçaram durante a prática - a penumbra, o ritmo lento da leitura, a plasticidade das vozes leitoras e a exaustão - foi possível depreender do texto reflexões não obtidas em leituras anteriores - silenciosas e individuais - do mesmo. Esse aspecto do "insight" (da revelação, do incômodo ou do estranhamento, próprios das leituras de fruição) mediante a leitura em voz alta não chegou a ser explorado ou desenvolvido na tese, mas foi especialmente importante enquanto indício dos possíveis desdobramentos que podem advir de práticas coletivas. Posteriormente (cerca de seis anos após a pesquisa de campo), esse sintoma ressurgiu em outras vivências, realizadas em ambientes educacionais. No entanto, consideramos relevante demarcar o percurso de descoberta de sinais tão sutis que, no entanto, podem revelar significativos dispositivos de leitura, de formação e de estudo. Segue abaixo a reprodução parcial dos registros de impressões - envolvendo práticas teatrais de leitura - feitos à época de sua realização: ${ }^{4}$

Registro 1: "[...] Ao chegar ao espaço da companhia, alguns integrantes já estavam presentes. Alguns conversavam, outros preparavam o jantar coletivo da noite: estrogonofe de frango, arroz e salada. Aguardei sentada ao sofá, olhando a biblioteca por eles organizada recentemente. Entre os títulos, livros de outros coletivos de teatro, de história econômica e política (Caio Prado fúnior, Celso Furtado), peças (Oswald de Andrade, Brecht, Plinio Marcos), romances e outros materiais. Foram catalogados e numerados. Visitei novamente a oficina de costura (com a qual muito simpatizo por conter elementos que remetem ao trabalho artesão, à feitura manual das coisas). Os atores do núcleo estavam ensaiando, mas logo desceram. Alguns permaneceram no espaço, outros foram embora. Começaria a jornada de ensaios com o PY, o núcleo de

\footnotetext{
3 Tese defendida em 2014 pela Faculdade de Educação da Universidade de São Paulo (FEUSP) intitulada Práticas de leitura no teatro de grupo: aproximações com a escola.

4 Os ensaios relatados ocorreram nos dias 27 de julho (Registro 1) e o1 de agosto de 2012 (Registro 2).
} 
formação. A primeira proposta da noite seria a continuidade de um trabalho que já vinha sendo realizado com o grupo a partir da peça de Dias Gomes, O pagador de promessas. O diretor já havia mencionado o trabalho que estava em fase de elaboração e as práticas envolvendo o texto. Com presença da atriz-assistente, propôs que fizessem mais uma vez o exercício de análise ativa do texto, o qual eu presenciaria pela primeira vez. O princípio de "análise ativa" é proveniente da autora Maria Ósipovna Knébel, estudiosa do método de Constantin Stanislavski.

Anteriormente, foram realizadas cerca de quatro "leituras de mesa" com o grupo e exercícios cênicos com trechos dos textos. Como nenhum personagem é fixo e não se pode "decorar" de modo automático as falas, colocar-se em cena para contracenar em conjunto exige de cada um o entendimento pleno dos objetivos e intenções de todas as personagens que a peça envolve. Essa abrangência de entendimento não parece ser alcançada facilmente. Por diversas vezes é preciso haver a interferência da assistente de direção para avisar qual cena vem a seguir, qual a intenção ou tema dela. Com o agravante do sono (é alta madrugada), as cenas transcorrem bem, mas lentamente e com muitas paradas. A trama está centrada em uma promessa feita por Zé do Burro, personagem principal que, acompanhado de sua esposa Rosa, está determinado a entrar com uma grande cruz na Igreja da Santa Bárbara, mas é impedido pelo padre que argumenta que a promessa fora feita a Iansã, uma deusa pagã, e que, portanto, estaria impedido de entrar na igreja com a cruz. Aos poucos, a trajetória das personagens vai se desenhando no palco. Em alguns momentos é possível vislumbrar lampejos de ritmo cênico. Após o exercício de análise ativa, foi feito um breve intervalo. Voltando, a proposta foi ler a peça A gaivota, de Anton Tchekhov, como parte do repertório de formação de leitura do grupo, predominantemente constituído por estudantes e trabalhadores. Uma peça extensa e exigente, às quatro horas da manhã, levada a cabo por pessoas que já haviam trabalhado e/ou estudado nos demais períodos. A leitura foi realizada durante um longo período de tempo (cerca de duas horas). Três integrantes não aguentaram e dormiram durante a leitura. Mas ela prosseguiu entre aqueles que permaneciam despertos. Não sei bem explicar o porquê, mas a leitura coletiva da peça, as vozes exaustas das atrizes e atores, a entonação livre (não enrijecida por impostação - que ora arrefecia ora inflamava àquela hora da madrugada - culminando em desfecho amalgamado ao amanhecer do dia, conferiram uma aura ao texto. De minha parte, houve uma percepção apurada que a primeira leitura da obra (feita há alguns anos, solitária e silenciosamente) não ofertara. Há nessas práticas de leitura uma disposição invejável no trato com o texto, um treino para a resiliência. Quanto à leitura da obra de Tchekhov - realizada daquela maneira, madrugada adentro -, posso afirmar que imprimiu lastros em minha recepção (especialmente um trecho da fala do personagem Trepliov), ${ }^{5}$ revelando aspectos diferentes

\footnotetext{
5 "Trepliov - [...] Tenho falado tanto sobre as novas formas e agora sinto que aos poucos estou mergulhado na rotina. (Lê) "O cartaz sobre o muro proclamava... rosto pálido emoldurado pelos cabelos negros..." Proclama, emoldurava... São lugares-comuns. (Risca-os do texto). Vou começar pelo ruído da chuva acordando o herói e o resto vai para o lixo. A descrição da noite enluarada é longa demais e artificial. Trigorin já aprendeu como fazer; para ele é fácil... Em seu texto,
} 
dos por mim percebidos antes. Nessa recepção de leitura, possivelmente influenciada pela sonoridade, pelo cansaço, pelos sentidos exaustos e talvez pelo esmaecimento da racionalidade - ficou ressaltada a impressão de um texto potente, dotado de nuanças e densidades que ressignificaram trechos, falas e reflexões".

Registro 2: "Hoje a ideia era tomar contato com as impressões de leitura do grupo a partir da leitura de A gaivota, ou seja, ter acesso ao diálogo pós-leitura, à retomada de elementos do texto, à troca de impressões, à partilha de reflexões, às estratégias de abordagem do texto, ao tratamento das questões por ele suscitadas e à verificação de como cada um compreendeu o texto lido. [...] Como a peça lida não está diretamente relacionada à montagem das cenas da proposta cênica propriamente dita - referente ao O pagador de promessas, de Dias Gomes - o diretor discorreu sobre o porquê da sugestão de leitura. Pelo que entendi, o grupo já estudou por um longo período (cerca de 6 ou 8 meses), textos teóricos do diretor teatral Stanislavski, leu e realizou exercícios cênicos com diferentes peças, entre elas Auto dos 99\%, de Oduvaldo Viana Filho; Quando as máquinas param, Abajur lilás e Homens de papel, de Plinio Marcos; Arena conta Zumbi, de Augusto Boal e Gianfrancesco Guarnieri; Liberdade, liberdade, de Millôr Fernandes; $\mathrm{O}$ rei da vela e Panorama do fascismo, de Oswald de Andrade; Ópera do malandro, de Chico Buarque de Holanda e Um bonde chamado desejo, de Tenesse Williams. Ao que tudo indica, pelo que depreendi na observação dos exercícios cênicos que tive a oportunidade de acompanhar, essas leituras têm finalidade de preparação, uma vez que consistem na primeira parte de um processo de criação. É possível perceber que há a preocupação com a formação literária e com a ampliação de conhecimentos teatrais do grupo (daí a necessidade de se ler uma grande quantidade de peças, visando à ampliação de repertório, e de se estudar e debater teorias teatrais). Mas uma outra dimensão teleológica, talvez de maior alcance, seria a da apropriação literária para a criação cênica. A escolha de A gaivota pelo diretor parece não ter sido aleatória. Durante os estudos de Stanislavski e dos processos de pesquisa e criação do Teatro de Arte de Moscou, essa peça é mencionada algumas vezes na descrição dos ensaios. O diretor da Antropofágica, munido de cerca de dez livros de autores teóricos diferentes que discorriam sobre a peça em questão, explicava sobre a relação dela com o teatro a que se propunha o ator e diretor russo. A gaivota foi encenada em 1901 e havia uma grande dificuldade por parte dos atores e atrizes do Teatro de Moscou em encená-la de maneira satisfatória. Os gestos histriônicos, as falas exageradamente falsas não combinavam com o texto dramático de Tchekhov, o que alimentava no diretor Stanislavski e em sua companhia, a busca por uma nova atuação, uma nova maneira de lidar com o texto dramático.

no açude brilha o gargalo de uma garrafa quebrada, negreja a sombra da roda do moinho e aí está, prontinha, a noite enluarada. Ao passo que no meu: luzes bruxuleantes, silenciosas, estrelas cintilantes, o som distante de um piano se esmaecendo no ar quieto e perfumado... Isso é torturante! (Pausa.) Sim, cada vez me convenço mais e mais que, quando se escreve, não se deve pensar em formas novas ou velhas, não é isso que importa, e sim permitir que o texto flua livremente de sua alma" (TсHEKHOv, 2004, p. 61). 
Alternando a leitura de trechos teóricos de diferentes autores, lidos pelas atrizes e atores do grupo, e a explanação sobre eles, o diretor foi alinhavando conceitos, impressões, anseios, mediando comentários e impressões vindos de uns e de outros. Um detalhe que chamou a atenção durante essas explanações é o fato da reflexão acerca do texto, bem como a sua análise, não consistir em um fim em si mesma. Todos os comentários, pensamentos e questionamentos são extremamente válidos por si, mas devem apontar para outro horizonte: o da criação. Esse diferencial de leitura merece ser estudado com mais afinco.

Em seguida, o diretor mencionou possibilidades de criação cênica que ele tinha em mente e que poderiam, ou não, virar cenas. Citando o teatro do invisível, de Augusto Boal, em que os atores interagem em contextos não-cênicos, o diretor comentou como seria interessante, por exemplo, pensar em outras situações em que o Zé do Burro (protagonista da peça de Dias Gomes) intentasse entrar em algum lugar, mas seria barrado por uma cruz ou por outros motivos simbólicos (querer entrar no cinema sem pagar, numa faculdade, ou no ônibus, por exemplo). Em meio aos estudos envolvendo a leitura de uma peça russa (escolhida também para ampliar o repertório de leitura de obras universais), lampejos de criação aconteceram, estabelecendo um diálogo constante entre conhecimento e criação.

Um insight também me ocorreu, e não pude deixar de comentar com o grupo. Sempre tive dificuldade em conciliar referenciais teóricos embasados em Stanislavski e os de Bertolt Brecht, muito provavelmente em função de uma visão deturpada acerca de uma suposta dicotomia entre "envolvimento" e "distanciamento" (ou estranhamento, possivelmente fruto das leituras de traduções norte-americanas daquilo que acabou se denominando o "método stanislavskiano"). Mediante a leitura da fala de Trepliov (no ensaio anterior) e de um trecho analítico de Arnold Hauser sobre a peça de Tchekhov, houve uma constatação quase óbvia de que essa aproximação BrechtStanislavski seria possivel, uma vez que o que de fato ocorrera foi uma cristalização das pesquisas de processos do Teatro de Arte de Moscou no que diz respeito, na verdade, a apenas alguns processos da companhia relativos, os que se apoiavam na vertente realista-naturalista. As afirmações e apontamentos específicos de um dos processos realizados pelo TAM foram possivelmente tomadas como uma metodologia dogmática em muitos casos. Portanto, aquilo que para mim era uma clara dicotomia, principalmente em virtude das proposições teóricas esboçadas por Stanislavski ao longo do capítulo "No limiar do subconsciente", do livro A preparação do ator, após a leitura coletiva (da peça, da fala de Trepliov sobre a forma estética) e as trocas de impressões de leitura ali realizadas, caiu por terra. Mais um forte indício de que as práticas de leitura e diálogos realizados em conjunto, com livre possibilidade de acertos e erros, de divagações, devaneios, de exposição de dúvidas e questionamentos podem ser enriquecedores. As diferentes leituras e comentários em grupo propiciam ainda, para além de subsídios para a criação teatral, uma apropriação literária que pode, posteriormente, gerar significados e transformações dentro e fora de cena". 


\section{Desdobramentos: leituras literárias na sala de aula}

A pesquisa fundamentada no acompanhamento e na análise de práticas de leitura junto a grupos teatrais teve como proposta, desde a sua concepção, aventar possibilidades que complementassem (ou arejassem) as práticas de leitura educacionais, tanto as realizadas na escola básica como no ensino superior. Com a finalidade de fomentar o desejável diálogo entre pesquisas acadêmicas e práticas sociais de leitura, gostaríamos de citar duas delas para ilustrar possibilidades descortinadas mediante considerações trazidas pelo estudo realizado.

Espaço curioso, a sala de aula se apresenta ainda como um dos poucos lugares em que agrupamentos humanos se formam, mantêm contato visual, auditivo, sensorial, porque, para o bem e para o mal, a presença é obrigatória. O corpo, docilizado (FouCAULT, 2009) cotidianamente, no ciclo final da educação regular (ensino médio), dificilmente apresenta atitude responsiva. Até mesmo a leitura em voz alta é repelida. $\mathrm{O}$ mesmo parece acontecer com as turmas de primeiros anos da faculdade. É justamente esse o recorte que aqui trazemos. As práticas de leitura ocorridas em aula partiram de premissas resultantes do percurso de pesquisa de doutoramento. O público essencialmente jovem, geralmente "indisposto" a leituras literárias, se reconhece, no entanto, enquanto leitor de textos da internet: acompanham blog, vlogs, mensagens, memes em redes sociais. Mas literatura, para quê?

\section{O vampiro de Curitiba na berlinda: as representações na obra de Dalton Trevisan}

Lecionando na rede pública estadual paulista há quase quinze anos, pude acompanhar e desenvolver alguns experimentos envolvendo leitura. Algumas delas geraram estudos específicos (leitura de obras literárias periféricas e marginais, por exemplo), outras se mostraram pouco profícuas. A mais recente (2018), envolvendo turmas de terceiro ano do ensino médio, merecem destaque pela recepção inicial festiva seguida de certo desagrado que gerou, por fim, distanciamento crítico e reflexivo especialmente no tocante à representatividade de personagens da obra lida.

No ensino básico público, os projetos de leitura tendem a ser sazonais. Sua efetivação é incerta, a estabilidade mais ainda. O último (bom, no meu entendimento) projeto de leitura de que participei - denominado Apoio ao Saber (2014) - consistiu na entrega de três obras literárias, previamente selecionadas pelo Ministério da Educação e Cultura (MEC), em caixinhas para cada um dos alunos e alunas. Em sebos da região, essas obras eram trocadas por um ou dois reais. Soube que pouquíssimos docentes se propuseram a trabalhar as obras distribuídas. O fato é que em 2018, do projeto encerrado em 2014, sobraram alguns livros que não chegaram a ser entregues aos alunos. É de conhecimento a escassez de materiais nas escolas públicas de modo geral. $\mathrm{O}$ único livro que consegui reunir em quantidade 
(cerca de 40 alunos por turma, portanto um jogo de 40 livros), foi Quem tem medo de vampiro?, uma coletânea de contos do autor curitibano Dalton Trevisan. Bastante polêmico e dono de um estilo literário bastante peculiar, o autor era desconhecido por todos os discentes envolvidos (alguns chegaram a comentar nunca ter lido um livro por inteiro).

A euforia primeira era ter contato com algum material. Num segundo momento, acreditaram pertencer ao gênero terror, em virtude do título. Num terceiro momento, após a leitura do primeiro conto, de cunho autobiográfico e linguagem rebuscada, expressões de desgosto foram alardeadas. Queriam trocar de livro (uma vez que a proposta era lê-lo na íntegra, cerca de dois a três contos por semana, seria um contato prolongado com a obra, ela nos acompanharia por um período), sentiam-se enganados pelo título, não haviam compreendido nada do que tinham acabado de ler e não viam sentido na leitura. Mediante o rechaço da obra, quase desisti da proposta. Mas lembrando da ausência de outros materiais de leitura e da importância da formação literária, insisti.

As leituras semanais transcorreram de modo controlado (impositivo é o termo) e, após a leitura de um dos contos - "Ismênia, moça donzela" -, magistralmente construído em formato epistolar, cuja trama apresenta uma personagem que de ingênua passa a obsessiva com o amante, os diálogos leitura se mostraram interessantes. Boa parcela das alunas comentou ter identificado, durante a leitura, um estereótipo de mulher interesseira que, por sua vez, corroborava uma negatividade predominante na representação da figura feminina nos contos do autor lidos anteriormente.

Os comentários vieram de alunas que pouco falavam durante as aulas de redação ou gramática. E o fato da leitura ser proferida majoritariamente por alunos homens, parece ter reforçado nelas essa impressão. Sugeri que nas aulas seguintes elas se predispusessem a ler, o que foi prontamente atendido. Além do aceite da leitura em voz alta, constatei que boa parte da turma começou a querer compreender o teor dos contos, a verificar que as palavras ali utilizadas não amedrontavam mais, eram do nosso livro de leitura, das aulas semanais, daquele estilo literário que, pela proximidade e constância, já se tornava familiar, ainda que colocado em xeque. Percebi também, além da atenção durante a leitura literária que não conseguimos mensurar ${ }^{6}$ ou quantificar, uma postura assertiva e encorajada das leitoras - que colocaram a representatividade das personagens do vampiro de Curitiba na berlinda -, talvez porque tenham percebido "falhas" ou fragilidades, por elas sagazmente detectadas, na obra em questão. De alguma maneira, alunas e alunos se sentiram confiantes e "autorizados" a ler e a pensar criticamente o que estava escrito nos livros, agora próximos e dessacralizados.

\footnotetext{
6 É solicitado um registro de leitura a cada aula, configurando uma espécie de diário de impressões de leitura, o que possibilita uma parcial noção de como a leitura está chegando no leitor. Ainda assim, é difícil ter acesso à recepção de fato.
} 


\section{Poiesis, aisthesis e khatarsis: leitura de poemas nas turmas de Co- municação Social}

Nas aulas de Língua Portuguesa do curso de graduação em Comunicação Social (Jornalismo), a leitura de literatura a princípio não causa espanto. É possível ler contos, crônicas diversas, textos teóricos. No entanto, ao propor a leitura de textos poéticos, os olhares costumam denotar ressalvas que se acirram quando a proposta de leitura se alia à produção poética. Inseridos num modus operandi cujo pressuposto é a tecnicidade, o pragmatismo, a racionalidade iluminista e científica, graduandos e graduandas costumam perguntar por que, afinal, trabalhar com poesia.

As primeiras leituras feitas em voz alta (pela professora ou por quem se dispõe a ler) geralmente são acompanhadas de expressões de enfado: "Onde está a objetividade?", "Para que servirá isso?", é o que parece comunicar veladamente boa parte dos alunos. A proposta - lidar com textos poéticos em turmas de habilitação em Jornalismo - já perdura há cinco anos e a reação inicial não difere muito. Uma ou outra exceção demonstra tímido entusiasmo.

No entanto, diante da insistência nas leituras, um desarme acontece: pela palavra poética, pela entonação da fala, pelo ambiente que se instaura, começamos a comungar poesia. Mediante o teor abordado, o enigma proveniente de certos trechos, as sonoridades, a palavra-faca, a palavra-vértebra, o léxico retomado em acepção deslocada, o campo semântico ampliando ou restringindo, a polissemia, tudo parece fazer sentido mesmo quando não completamente entendido.

A partir da segunda aula de leitura, os semblantes já aparentam certa animação ao travar contato com o multifacetado Drummond, o poeta das coisas inúteis Manoel de Barros, a malemolência de Allan da Rosa e, como são textos poéticos (o que amplia o espectro da seleção de textos para além do gênero poema), com a riqueza de exploração estilística de Guimarães Rosa ou a precisa escrevivência de Conceição Evaristo. Outras poesias vão adentrando o espaço após as leituras - há proposições, direcionadas ou espontâneas, que se desencadeiam resultantes artísticas musicais, plásticas, teatrais, audiovisuais. Tudo por uma "concessão" conferida pelas leituras literárias.

Defendendo o caráter prazeroso na comunicação literária, o teórico da estética da recepção, Hans Robert Jauss, em seu estudo sobre a experiência estética, enumera as seguintes categorias envolvidas na fruição estética: a aisthesis (prazer advindo da percepção estética pelo reconhecimento da obra), a poiesis (prazer ante a obra que realizamos ou à conversão de uma obra em algo nosso) e a katharsis (prazer proveniente da transformação, liberação ou sublimação frente a obra) (JAUSS, 2002). Para Jauss, as categorias fundamentais não devem ser compreendidas hierárquica ou subordinadamente, mas sim de modo relacional.

Das três, a poiesis parece se aproximar do que é percebido nas práticas de leitura literária de textos poéticos acima descritas: a constância das leituras em voz 
alta, a presença da palavra poética no próprio corpo ou no corpo alheio, a escuta de textos que escapam da lógica estritamente racional (e também os diálogos pósleitura sobre versos, metáforas ou efeitos) favorecem o que comumente denominamos "apropriação" - da palavra, do texto, da literatura e da poesia - o que Jauss denomina poiesis. ${ }^{7}$

A aproximação corpórea entre texto literário e leitor se dá, nessas práticas, pelo atravessamento do sujeito pela literatura. E pela atribuição de sentidos à literatura pelo leitor. Ver escrito, dizer em voz alta, ouvir, ler-reler, comentar e se apropriar aparecem como ações que conferem organicidade às leituras literárias e suposta "autorização" aos envolvidos para adentrar as searas literárias com mais propriedade e legitimidade.

Pensando na dimensão formativa da leitura (que poderia se aproximar do conceito de katharsis abordado por Jauss), os futuros e futuras jornalistas são os que lidarão com as narrativas e perspectivas do outro. ${ }^{8}$ Deixar-se conduzir - pela literatura, pela singularização do universal (SARTRE, 2015, p.56) que cada obra literária ou autoria envolve - e, sensivelmente, saber conduzir, são ações aparentemente beneficiadas pela experiência estética (aisthesis) proporcionada por práticas coletivas de leitura literária. A experiência de leitura nesses moldes, além de envolver perspectivas diferentes, proporcionando o contato e a imersão com a alteridade por intermédio da literatura, também traz em seu bojo a experiência de si, do corpo imbricado no texto literário e na palavra - que passam a ser seus, porque ditos, ouvidos e sentidos em si.

\section{Algumas considerações: a materialidade das leituras coletivas}

As práticas coletivas de leitura mobilizam materialidades e adquirem características que as práticas individuais e silenciosas, por suas especificidades, não proporcionam. Podemos citar:

1. a influência do espaço físico e simbólico instaurado por um agrupamento humano específico, o que permite uma atmosfera propícia à leitura conjunta;

7 As práticas de leitura de textos poéticos dividem-se em duas etapas. Uma primeira destinada à leitura de poetas reconhecidos, e a segunda dedicada à leitura comentada de textos poéticos dos discentes. Apesar de não fazer parte do escopo desse estudo, é interessante notar a satisfação posterior dos envolvidos quando seus poemas são lidos e comentados com a mesma seriedade e cuidado com que são tratados os poemas de autoria já legitimada pelo campo literário.

8 Jauss (2002, p. 98) ressalta a experiência estética como: "Na conduta estética, o sujeito sempre goza mais do que de si mesmo: experimenta-se na apropriação de uma experiência de sentido do mundo, ao qual explora tanto por sua própria atividade produtora, quanto pela integração da experiência alheia e que, ademais, é passível de ser confirmado pela anuência de terceiros. $O$ prazer estético que, desta forma, se realiza na oscilação entre a contemplação desinteressada e a participação experimentadora, é um modo da experiência de si mesmo na capacidade de ser o outro, capacidade a nós aberta pelo comportamento estético". 
2. o compartilhamento permanente de referenciais variados e de reflexões individuais e coletivas que podem acrescentar, complementar ou modificar a recepção;

3. há por vezes uma ênfase processual envolvendo as leituras e os trabalhos, ou seja, as leituras literárias coletivas podem fazer parte de um projeto maior e dialogar com outros processos contínuos de formação e criação;

4. a retomada de ritos e a valorização do acontecimento (ato da leitura) enquanto experiência, o que remete a ancestralidades;

5. a predisposição à ação e a capacidade de improviso por parte dos leitores e ouvintes (quem está ouvindo pode ser solicitado a qualquer momento, seja para continuar a leitura);

6. o treino disciplinado e exigente da escuta (alguns integrantes podem até dormir durante as leituras, mas enquanto acordados, são deles exigidos atenção e concentração plenas, especialmente mediante a leitura alheia);

7. a presença de textos de repertório e a capacidade de memorizá-los (trechos de textos literários, teóricos, de peças etc. são proferidos ou aludidos pelos integrantes sempre que fazem sentido em algum contexto, o que potencializa a apropriação textual);

8. o caráter por vezes teleológico das leituras literárias (ler para fomentar a criação, para a construção de personagens, para ter acesso a outras obras do autor com que se vai trabalhar, para ampliação do repertório de leitura; como acesso a diferentes perspectivas culturais; como maneira de acessar as alteridades e subjetividades; como modo de analisar outras escritas, estilos e recursos de linguagem etc.), dentre outros aspectos;

9. a importância da mediação, seja na figura do professor, do diretor, do facilitador que pode sugerir obras, autores, modos de ler, que proporciona relações intertextuais e colabora na compreensão quando necessário, que pode instaurar práticas mais tradicionais ou mais transgressoras de leitura.

A elas somam-se implicações próprias da corporeidade exigida em leituras em voz alta: 1) o cuidado com a matéria acústica; 2) a percepção das sonoridades provenientes das palavras; 3) o estudo do ritmo, da prosódia e das entonações; 4) o manejo das pausas gramaticais, psicológicas e dramáticas; e 5) a presença do corpo, do olhar e das subjetividades envolvidas no ato de leitura próprio e do outro.

Sobre as subjetividades imbricadas nas práticas investigadas, seria interessante compreendê-las sob a concepção de corpo e performance defendida por Paul Zumthor, medievalista e pesquisador da oralidade. O autor afirma que as formas poéticas transmitidas pela voz adquirem relativa autonomia em relação ao texto. ${ }^{9}$

9 "Com efeito, nas formas poéticas transmitidas pela voz (ainda que elas tenham sido previamente compostas por escrito), a autonomia relativa do texto, em relação à obra, diminui muito: podemos 
Quanto à aproximação que o mesmo autor faz entre literatura e teatro, ou sobre a característica performática existente no ato da leitura, podemos citar outros estudos realizados por diferentes autores, que se debruçaram sobre questões relacionadas à leitura, em que semelhanças são mencionadas. Por exemplo, o playing e o game, são categorias ambivalentes engendradas no ato de leitura - respectivamente relacionadas ao imaginário do sujeito (playing) e ao distanciamento crítico e reflexivo (game) - entendido assim como "jogo de representação e de regras" (PicARD apud Jouve, 2002, p. 112). Ou as relações de texto-leitor fundamentadas na passagem dos sistemas fechados de leitura (decodificação dos textos) para um sistema mais aberto, aquele que consideraria o leitor como alguém capaz de preencher os vazios textuais, as lacunas, com suas interpretações e referenciais específicos, ou seja, como um agente de um "modo de criação de mundo" (ISER, 2002, p. 106). Umberto Eco também traça apontamentos a respeito da função educativa da literatura que se aproximam das regras do jogo teatral. De acordo com os combinados e regras, os jogadores desse último precisam agir dentro de algumas condicionantes. Por exemplo, no teatro fórum, cada personagem do teatro-tribunal precisa exercer minimamente as funções requeridas pelo papel social que ali desempenham. Não é possível fugir completamente às regras do jogo sob o risco de com ele romper. Isso também acontece com as obras literárias. O que está ali escrito pelo autor não será modificado pelos leitores: por exemplo, não se pode mudar o fato de que Desdêmona foi morta por Otelo. O leitor detém o espaço da interpretação e do preenchimento das lacunas deixadas pelo texto. Mas, quanto à estrutura da obra, seu enredo, seu desfecho, ele não tem poder. Eco credita a essa impossibilidade de mudança um traço educativo pela leitura literária. ${ }^{10}$

Muitos elementos aqui atribuídos às práticas coletivas de leitura poderiam muito bem ser relacionados a práticas particulares e silenciosas de leitura. A solidão é curiosamente característica em ambas, no sentido rosiano: "a colheita é comum, mas o capinar é sozinho". A reflexão, a percepção e a atribuição de sentidos ao texto lido acontecem no "seio da solidão", ${ }_{11}^{11}$ como salienta Marcel Proust, mesmo em leituras públicas, por exemplo.

supor que, no extremo, o efeito textual desapareceria e que todo o lugar da obra se investiria dos elementos performanciais, não textuais, como a pessoa e o jogo do intérprete, o auditório, as circunstâncias, o ambiente cultural e, em profundidade, as relações intersubjetivas, as relações entre a representação e o vivido. $\mathrm{O}$ termo e a ideia de performance tendem (em todo caso, no uso anglo-saxão) a cobrir toda uma espécie de teatralidade: aí está um sinal. Toda "literatura" não é fundamentalmente teatro?" (ZumTHor, 2007, p. 17-18).

10 "Mas estes jogos (mecanismos hipertextuais, jam session, histórias interativas) não substituem a verdadeira função educativa da literatura, função educativa que não se reduz à transmissão de ideias morais, boas ou más que sejam, ou à 175 transformação do sentido do belo. [...] É a descoberta de que as coisas aconteceram, e para sempre, de uma certa maneira, além dos desejos do leitor. O leitor tem que aceitar essa frustração, e através dela experimentar o calafrio do destino" (ECO, 2003, p. 19-20).

11 "O que é preciso, portanto, é uma intervenção que, vinda de um outro, se produza no fundo de nós mesmos, é o estímulo de um outro espírito, mas recebido no seio da solidão" (Proust, 2011, p. 38). 
O que se pretendeu recuperar no presente artigo foram as outras possibilidades de leitura imbricadas nas práticas fundadas no ler coletivamente em voz alta. Percebe-se certo ranço, provavelmente proveniente da escolarização da leitura no século XIX, para com a leitura em voz alta, vista por vezes como ultrapassada, retrógrada. Ainda mais na era da velocidade, da otimização de tempo, do trabalho incessante, do ritmo pautado pela lógica da produtividade e da individualização. A criação de espaços simbólicos para compartilhamentos e trocas oriundas de leituras literárias chega a ser subversiva, uma vez que confere acesso ao campo literário, proporciona partilhas de impressões a partir do contato com as subjetividades presentes nas obras lidas e nos leitores envolvidos e rompe com a tendência ao isolamento, tão predominante na atualidade.

Talvez nós sejamos capazes de permanecer gerando a experiência narrativa benjaminiana (BENJAMIN, 1994) também por intermédio de práticas de leitura. Há algo de ancestral ou arquetípico quando as rodas de leitura e de diálogo são refeitas. A figura do lector cubano lendo para os que trabalham manualmente as folhas de charuto ou os líderes tribais que entoam narrações e cânticos em volta do fogo reiteram práticas que, consciente ou inconscientemente, nos são necessárias. A leitura que passa por nós, que fica, que faz acender "luzinhas que piscam" - como para o menino em Infância, de Graciliano Ramos - pode chegar até nós por diferentes vias, inclusive as coletivas, as corpóreas, as que nos trazem a literatura em alto e bom som.

\section{Referências}

BENJAMIn, Walter. Magia e técnica, arte e política: ensaios sobre literatura e história da cultura. São Paulo: Brasiliense, 1994 .

Chartier, Roger. Práticas da leitura. São Paulo: Estação Liberdade, 2001.

Chartier, Roger. A aventura do livro - do leitor ao navegador. São Paulo: Editora UNESP, 1999.

CrARY, Jonathan. Suspensões da percepção - atenção, espetáculo e cultura moderna. São Paulo: Cosac Naify, 2013.

Eco, Umberto. "Sobre algumas funções da literatura". Sobre a literatura. Rio de Janeiro: Record, 2003.

Foucault, Michel. Vigiar e punir - história da violência nas prisões. Petrópolis: Vozes, 2009.

Iser, Wolfang. "O jogo do texto". In: Lima, L. da C. (org.). A literatura e o leitor textos da estética da recepção. São Paulo: Paz e Terra, 2002. 
Jauss, Hans Robert. "O prazer estético e as experiências fundamentais da Poiesis, Aisthesis e Katharsis". In: LimA, L. da C (org.). A literatura e o leitor - textos da estética da recepção. São Paulo: Paz e Terra, 2002.

Jouve, Vincent. A leitura. São Paulo: Editora UNESP, 2002.

Manguel, Alberto. Uma história da leitura. São Paulo: Companhia das Letras, 1997.

Proust, Marcel. Sobre a leitura. Campinas: Pontes Editores, 2011.

Rouxel, Annie; Langlade, Gérard; Rezende, Neide Luiza de (Orgs.). Leitura subjetiva e ensino de literatura. São Paulo: Alameda, 2013.

SARtre, Jean-Paul. O que é a subjetividade? Rio de Janeiro: Nova Fronteira, 2015.

Tcheкhov, Anton. A gaivota e Tio Vânia. São Paulo: Editora Veredas, 2004.

Zumthor, Paul. Performance, recepção, leitura. São Paulo: Cosac Naify, 2007.

Recebido em o5 de julho de 2018.

Aprovado em 26 de fevereiro de 2019

\section{Resumo/Abstract/Resumen}

Literatura em alto e bom som: experiência e materialidade em leituras literárias coletivas

\section{Mei Hua Soares}

À leitura literária atribui-se comumente aspectos silenciosos, individuais e solitários. Mas outras práticas de leitura de literatura - realizadas histórica e contemporaneamente - fazem parte de nossa cultura, dentre elas, as públicas e em voz alta. Partindo de premissas depreendidas de tese de doutoramento sobre práticas de leitura coletivas e de relatos envolvendo exemplos ocorridos em salas de aula (ensino superior e no médio) e em um grupo teatral, pretende-se tecer reflexões sobre as possibilidades de recepção mobilizadas nesse tipo de leitura.

Palavras-chave: leitura, literatura, práticas coletivas, recepção, corporeidade

\section{Literature Out Loud: Experience and Materiality in Collective Literary Re- adings}

\section{Mei Hua Soares}

The reading of literature is commonly thought of as a silent, individual and solitary activity. But other practices of reading literature - historically and contemporaneously - are part of our culture, among them, public readings and reading 
aloud. Based on the premise of a doctoral thesis on collective reading practices and examples from classrooms (middle and high school) and from a theatrical group, we intend to reflect on the reception possibilities activated in this type of readings.

Keywords: reading, literature, collective practices, reception, corporeity.

Literatura en alto y buen sonido: experiencia y materialidad en lecturas literarias colectivas

\section{Mei Hua Soares}

A la lectura literaria se atribuyen comúnmente aspectos silenciosos, individuales y solitarios. Pero otras prácticas de lecturas literarias - realizadas histórica y contemporáneamente - forman parte de nuestra cultura, entre ellas, la lectura pública y la lectura en voz alta. A partir de premisas derivadas de una tesis de doctorado sobre prácticas de lectura colectiva y de relatos, incorporando ejemplos de lo acaecido en aulas de enseñanza superior y media, como también en un grupo teatral; se pretende tejer reflexiones sobre las posibilidades de recepción movilizadas en este tipo de lectura.

Palabras clave: lectura, literatura, prácticas colectivas, recepción, corporeidad. 